\title{
Developing a Social Enterprise Performance Scale and Examining the Relationship Between Entrepreneurs' Personality Traits and Their Perceived Enterprise Performance
}

\section{Chao-Tung Liang ${ }^{1}$, Li-Pei Peng ${ }^{2}$, Shu-Nung Yao3, Chaoyun Liang ${ }^{4}$}

\begin{abstract}
On the basis of the lack of measurement tools and the research gap regarding social entrepreneurship, three studies were conducted to develop a new measure of social enterprise (SE) performance that is empirically valid and easy to administer. The purpose of this measure was to examine the relationship between entrepreneurs' personality traits and their perceived SE performance. The results indicated that SE performance can be assessed using four dimensions: personal issues, social aspects, business elements, and service programmes. Extraversion positively influenced service programmes, and openness negatively affected service programmes. Neuroticism and conscientiousness positively predicted personal issues and service programmes, and agreeableness positively predicted all dimensions of perceived SE performance. The results also demonstrated the curvilinear relationship of the U-shaped curve between neuroticism and personal issues and the social aspects of SE performance. Furthermore, the results showed the curvilinear relationship of the inverted U-shaped curve between agreeableness and the four dimensions of SE performance.

Keywords: performance assessment, personality traits, scale development, social enterprise, social enterprise performance scale.

1 Chao-Tung Liang, Assistant Professor, Department of Cultural Creativity and Digital Media Design,

Lunghwa University of Science and Technology, Taoyuan, Taiwan, e-mail: liangdondon@gmail.com.

2 Li-Pei Peng, Associate Professor, Department of Bio-Industry Communication and Development, National Taiwan University, Taipei, Taiwan, e-mail: lipei@ntu.edu.tw.

3 Shu-Nung Yao, Postdoctoral Researcher, Department of Bio-Industry Communication and Development, National Taiwan University, Taipei, Taiwan, e-mail: artcatuk@gmail.com.

4 Chaoyun Liang, Professor, Department of Bio-Industry Communication and Development, National Taiwan University, Taipei, Taiwan, e-mail: cliang@ntu.edu.tw. Correspondence concerning this article should be addressed to Chaoyun Liang, Department of Bio-Industry Communication and Development, National Taiwan University, No. 1, Sec. 4, Roosevelt Road, Taipei, 10617, Taiwan. Electronic mail may be sent to cliang@ntu.edu.tw.
\end{abstract}




\section{INTRODUCTION}

Social entrepreneurship has captured the attention of non-profit organisations, philanthropists, and academics in recent years. Social enterprises (SEs) are businesses intended primarily for social benefit. They are innovative agents that engage the market and harness its wealth-generating powers to serve disadvantaged social groups and achieve social transformation (Pelchat, 2005). SEs use business methods to advance their social, environmental, and human-justice agendas (Vitiello \& Wolf-Powers, 2014). They create non-profit-sector jobs, foster workforce development, and assist people in generating supplemental income, often by strengthening ties between entrepreneurs and the formal economy and building social capital.

Although SEs are common in Europe and the United States, they are new to Asia. Before 2007, most people in Taiwan perceived a social contribution as a traditional public service such as fundraising for philanthropic organisations, assisting with natural disaster relief, or teaching children in remote areas (Lin, 2009). At that time, non-profit organisations adopted business strategies to solve social problems even though they did not identify themselves as SEs. The development of SEs in Taiwan remains at an early stage and is facing numerous challenges. In addition to the lack of governmental support, Lin (2009) indicated that minimal support from academia has also hampered the progress of SE development in Taiwan. Without systematically analysing the functioning of SEs, potential supporters should not invest in SE development because they would lack knowledge regarding the sustainable operation of SEs.

Previous studies have determined that entrepreneurs are a key factor in understanding the operation of a SE (Bird, Schjoedt \& Baum, 2012), and the personality traits of entrepreneurs predict their job performance (Zhao and Seibert, 2006). Furthermore, thus far, the social impact or organisational performance of a SE have been analysed mainly through the case study method combined with a social return on investment (SROI) (Krlev, Münscher \& Mülbert, 2013). However, the data collected from case studies cannot necessarily be generalised to the wider population, and a precise cause-andeffect-relationship is difficult to construct on the basis of this data. Moreover, an SROI investigation typically involves sensitive financial and operational issues, creating research difficulties. To fill the aforementioned research gap, the research team conducted a series of studies to develop a new self-report measure of SE performance that is empirically valid and easy to administer to test the relationship between entrepreneurs' personality traits and their perceived SE performance.

This article presents the findings of three studies. The first study was conducted to develop a self-report scale to assess SE performance; the second 
study was conducted to confirm the factor structure of this scale and test the degree of measurement invariance of this scale across genders; and the third study was conducted to examine the relationship between entrepreneurs' personality traits and their perceived SE performance. The personality traits were assessed using the widely accepted five-factor model (FFM) (Goldberg, 1992; Thompson, 2008), which refers to the traits of extraversion, openness, neuroticism, conscientiousness, and agreeableness. The results of this study could make the assessment of SE performance much more practical than before and clarify the influence of entrepreneurs' personality traits on their perceptions of SE performance.

\section{THEORETICAL FRAMING OF RESEARCH ISSUES}

\section{Social entrepreneurship}

A SE is perceived as a venture intended primarily for social benefit, the surpluses of which are principally reinvested for social purposes rather than maximising profit for shareholders and owners (DTI Social Enterprise Unit, 2003, p.6). In other words, a SE is an organisation intended to resolve social issues through entrepreneurial action. SEs are increasingly compelled to engage in the market economy, and SEs share characteristics with earnedincome ventures initiated by conventional non-profits because both are driven by the dual goals of social benefit and trade revenues (Katre \& Salipante, 2012).

Generally, any business activity that contributes to the resolution of social problems constitutes social entrepreneurship. Therefore, social entrepreneurship can refer to innovative activities with social objectives in either the for-profit or non-profit sector, or across sectors, such as businesses that combine for-profit and non-profit structures (Austin, Stevenson \& Wei-Skillern, 2006). The narrower definition of social entrepreneurship includes only environmentally sustainable services provided by SEs that can contribute to resolving socioeconomic problems (York \& Venkataraman, 2010). SEs have been modelled on the tenets of 'not-for-profit' charitable organisations that have community-oriented motives. Additionally, SEs have used their community-spirited motives to attract human and social capital and engendered survival strategies premised on grant dependency. Chell (2007) argued that SEs should be self-sustaining in the long term. Furthermore, the definition of entrepreneurship should be modified to include the creation of 'social and economic value', which may be applied to private, entrepreneurial ventures as well as SEs. 


\section{SE performance}

With the increasing use of managerial practices, optimisation has become crucial for organisational performance (Hall, Daneke \& Lenox, 2010). The issue of performance measurement in SEs has gained increasing relevance among researchers and practitioners. Prior research indicated that performance measurement for social enterprises must include both organisational performance and social impact (Arena, Azzone \& Bengo, 2014; Hadad \& Găucă, 2014). Previous studies also suggested that entrepreneurs themselves, management teams, and service programmes provided by SEs play critical roles in the performance of SEs (Boluk \& Mottiar, 2014; Smith, Bell \& Watt, 2014; York \& Venkataraman, 2010). Therefore, in the current study, the performance measurement of SEs is discussed by four categories: personal issues, social aspects, business elements, and service programmes.

Regarding personal issues, Hockerts and Wüstenhagen (2010) suggested that in the early stages of an industry's sustainability transformation, new entrants are more likely than incumbents to pursue sustainability-related opportunities. Marshall and Beachy (2010) also emphasised the importance of human resources in a SE. By asking 32 technology entrepreneurs how they generate creative ideas for developing innovative products, Gemmell, Boland \& Kolb, (2012) found that the highest ideational productivity occurs when 'trusted partners' exchange and refine ideas through a form of shared cognition. In addition, several studies identified the crucial aspects of human resources in a SE, including internal knowledge, entrepreneurial orientation, and entrepreneurial intensity (De Clercq et al., 2013; Kreiser, Patel \& Fiet, 2013).

With respect to the social aspects of SEs, previous studies have indicated that a SE focuses on obtaining entrepreneurial rents while simultaneously improving local and global social and environmental conditions (Cohen \& Winn, 2007; Dean \& McMullen, 2007; Zahra et al., 2014). Corner \& Ho (2010) studied opportunity identification in the social entrepreneurship literature and found that SE practitioners tend to perceive a social need and prospective ideas for addressing it. Korsgaard \& Anderson (2011) held that the social conditions of entrepreneurs, as well as the social nature of market opportunities, affect the entrepreneurial process. Therefore, understanding that enterprises are socially situated is useful. Moreover, according to Casson \& Giusta (2007), although the government is afforded the major role of trust-broker, its reputation may be undermined if it lacks the competence to intervene effectively.

Regarding business elements, Meyskens, Robb-Post, Stamp, Carsrud \& Reynolds (2010) indicated that substantial relationships existed amongst partnerships, financial capital, innovativeness, organisational structure, and knowledge transferability. Parrish (2010) engaged in an intensive 
empirical study investigating the organisational design expertise necessary for sustainability-driven entrepreneurs to succeed in a competitive market and identified five crucial principles of organisational design. These findings suggested that the expertise required for the success of a venture differs depending on entrepreneurial values and motives. De Clercq et al. (2013) further indicated that higher levels of internal knowledge sharing related to stronger entrepreneurial orientation. Furthermore, De Clercq et al. (2013) found that higher levels of knowledge sharing resulted from higher levels of trust and goal congruence.

In addition, programmes provided by SEs are considered critical activities of SEs (Marshall \& Beachy, 2010). York and Venkataraman (2010) suggested that SE practitioners contribute to solving environmental problems by assisting extant institutions in achieving their goals and creating new and sustainable products, services, and institutions. Kreiser et al. (2013) indicated that an increase in the strength of social ties is negatively associated with founding activities, whereas an increase in the number of social ties is positively associated with founding activities. Kreiser et al. (2013) also asserted that entrepreneurial intensity mitigates the negative relationship between an increase in tie strength and founding activities and that social competence reinforces the positive relationship between an increase in the number of ties and founding activities.

\section{Personality traits}

The FFM (Goldberg, 1992) is a widely accepted personality model (Ariani, 2013), which allows researchers to organise various personality traits into a meaningful set of constructs to identify consistent relationships (Zhao \& Seibert, 2006). In developing the 100-item model structure, Goldberg (1992) noted that relatively small sets of variables could serve as FFM adjective markers. Subsequently, Saucier (1994) developed the 40-item Mini-Marker subset of variables, which were similar to the prototypical cores of the FFM of personality. Thompson (2008) then developed the International English BigFive Mini-Markers (IEBFMM) and confirmed the invariance of the FFM structure across several cultures. The FFM structure comprises the five dimensions of extraversion, openness, neuroticism, conscientiousness, and agreeableness.

Extraversion has been described as sociable, talkative, and self-assured behaviour (McCrae \& Costa, 1991). Extraverts are likely to share their ideas with others, thereby enabling the occurrence of idea cross-fertilisation. People exhibiting high degrees of extraversion are typically cheerful and optimistic, enjoy interacting with people and large groups, and seek excitement and stimulation (Lin, Liang, Chang and Liang, 2015). They are competent in 
developing networks (Zabelina, Robinson \& Anicha, 2007), but can suppress the expression of excessive ambition and impulses that are socially inappropriate (Wolff \& Kim, 2012). By contrast, people who exhibit introversion prefer to process information internally and frequently withhold ideas because they fear negative evaluation (Van Der Molen, Schmidt \& Kruisman, 2007). They are typically reserved, independent, and consistent (Zhao \& Seibert, 2006).

Open people are generally described as having a preference for variety, aesthetic sensitivity, intellectual curiosity, active imaginations, and independent judgment, and are attentive to inner feelings, broad-minded, reflective, flexible, autonomous, and unconventional (Ariani, 2013; Rothmann \& Coetzer, 2003). People having high openness scores have more varied perspectives and an enhanced ability to absorb and combine new information. They typically seek new experiences as well as explore novel ideas and should, therefore, be effective at the cognitive exploration and cross-fertilisation of ideas (Baer, Oldham, Jacobsohn \& Hollingshad, 2008). However, research has shown that strong openness can render people unable to focus on tasks that require intense concentration because of their intellectual curiosity, which is easily piqued by novelty (Rose, Fogg, Helmreich \& McFadden, 1994). By contrast, a person exhibiting a low degree of openness can be characterised as having a narrow range of interests and behaving in a conventional and unanalytical manner (Rothmann \&Coetzer, 2003; Zhao \& Seibert, 2006).

Neuroticism is a tendency to experience negative emotional states, such as anxiety, depression, fear, sadness, hostility, anger, guilt, disgust, and vulnerability. Neurotic people are typically insecure, irritable, easily disturbed, and lacking in self-confidence. They are generally impulsive and have been observed to undermine the social fabric of teams (Denissen \& Penke, 2008; Rothmann \& Coetzer, 2003). People exhibiting high levels of neuroticism are prone to irrational thought, impulsive behaviour, and applying poor coping strategies in stressful situations (Rothmann \& Coetzer, 2003). However, people with high levels of neuroticism are likely to provide others with candid feedback regarding their ideas, which can stimulate additional ideas or cause members to elaborate on their ideas, increasing a team's creativity (Baer et al., 2008). By contrast, people with low neuroticism scores are typically self-confident, calm, relaxed, and able to face stressful situations without becoming upset (Zhao \& Seibert, 2006). In addition, a previous study observed a stronger relationship between neuroticism and job performance when the levels of neuroticism were in the mid-range than when the trait was at either extreme (Le, Oh, Robbins, llies, Holland \& Westrick, 2011).

Conscientiousness refers to a person's degree of organisation, persistence, self-control, hard work, active planning and performance of tasks, and motivation to accomplish goals (Barrick \& Mount, 1993; Zhao \& Seibert, 2006). 
People with high conscientiousness scores are purposeful, responsible, reliable, ambitious, determined, and achievement-oriented. However, people exhibiting strong conscientiousness can focus excessively on task accomplishment, causing them to disregard novel ideas and adhere rigidly to established thoughts and behaviours (Le \& Pine, 2003). High degrees of conscientiousness can lead to behaviours that are considered annoying, such as fastidiousness, compulsive neatness, or workaholism (Ariani, 2013). People with low conscientiousness scores do not necessarily lack moral principles, but they are less exacting in applying such principles (Rothmann \& Coetzer, 2003). In addition, several studies have provided evidence of a positive curvilinear relationship between conscientiousness and performance, and the conscientiousness trait benefits performance in high-complexity tasks, such as creative thinking and unstructured work (Le et al., 2011; Penney, David \& Witt, 2011).

Agreeable people are described as altruistic, considerate, friendly, caring, compassionate, gentle, warm, and willing to cooperate in conflict situations, and they prefer positive interpersonal relationships (Lin, Liang, Chang \& Liang, 2015). Because highly agreeable people are unlikely to compete for limited resources or be preoccupied with avoiding confrontations and conflicts, they can be excessively self-effacing (Bernardin, Cooke, Villanova, 2000) and might not claim credit for their contributions (llies, Johnson, Judge \& Keeney, 2011). In other words, this trait can inhibit the willingness to negotiate aggressively, protect self-interest, and influence or manipulate others for personal gain (Zhao \& Seibert, 2006). By contrast, a person exhibiting low levels of agreeableness can be characterised as manipulative, self-centred, ruthless, egocentric, sceptical of other people's intentions, and competitive rather than cooperative (Rothmann \& Coetzer, 2003). Disagreeable people are typically selfish. Their scepticism regarding the motives of others often causes them to be suspicious, unfriendly, and uncooperative (Costa \& McCrae, 1992). Therefore, they are unlikely to establish a supportive network or form meaningful social exchange relationships with others (Michel et al., 2011). Recent metaanalytic studies have reported strong associations between personality traits and entrepreneurship (Brandstätter, 2011; Zhao \& Seibert, 2006). Costa \& McCrae (1992) described sales persons as prototypical extraverts. Entrepreneurs typically adopt the roles of salespersons, whether they persuade a venture capitalist to support their proposed idea or convince a client to purchase their services (Zhao \& Seibert, 2006). In addition, prior research has shown that openness is related to successfully adapting to change (Yap, Anusic \& Lucas, 2012). Entrepreneurs often need to explore new ideas, use their creativity to solve problems, and apply innovative approaches to developing products, services, and business strategies (Zhao \& Seibert, 2006). Moreover, entrepreneurs have been described as highly self-confident 
(Chen, Greene \& Crick, 1998) and having strong beliefs in their abilities to control outcomes (Simon, Houghton \& Aquino, 2000); these traits define low levels of neuroticism.

Furthermore, previous studies have indicated that entrepreneurs are highly motivated to achieve goals (Stewart \& Roth, 2004; Wang \& Liang, 2015). In other words, they exhibit high levels of conscientiousness. Furthermore, entrepreneurs typically operate with less access to legal protection and a thin financial margin of error because of limited resources, and they tend to be self-centred and competitive. In other words, they exhibit low levels of agreeableness (Zhao \& Seibert, 2006). Several meta-analytic studies have shown that entrepreneurs typically have high extraversion, openness, and conscientiousness scores and comparatively lower neuroticism and agreeableness scores (Brandstätter, 2011; Zhao \& Seibert, 2006). Based on the aforementioned studies, the research team proposed the following seven hypotheses:

H1: Extraversion, openness, and conscientiousness positively predict SE performance.

H2: Neuroticism and agreeableness negatively predict SE performance.

H3: The relationship between extraversion and SE performance is curvilinear, which can be illustrated by an inverted U-shaped curve.

H4: The relationship between openness and SE performance is curvilinear, which can be illustrated by an inverted U-shaped curve.

H5: The relationship between neuroticism and SE performance is curvilinear, which can be illustrated by a U-shaped curve.

H6: The relationship between conscientiousness and SE performance is curvilinear, which can be illustrated by an inverted U-shaped curve.

H7: The relationship between agreeableness and SE performance is curvilinear, which can be illustrated by an inverted U-shaped curve.

\section{STUDY 1: EXPLORATORY FACTOR ANALYSIS}

\section{Method}

Participants. The participants in this study were either leaders or high-level managers of SEs in Taiwan. These participants served as the calibration sample for testing the number of factors in the data by using an exploratory factor analysis (EFA). The most appropriate structure of the SE performance scale (SEPS) was determined by the EFA results. Of the 196 participants, 190 completed all parts of the study. The majority (61.05\%) were male; $25.26 \%$ did not have bachelor's degrees, $34.21 \%$ had bachelor's degrees, and $40.53 \%$ 
had master's (and above) degrees; $23.68 \%$ ranged in age from 20 to 30 years, $25.26 \%$ ranged from 31 to 40 years, $30.00 \%$ ranged from 41 to 50 years, and $21.06 \%$ ranged from 51 and above.

Measure. Based on previous studies (Arena et al., 2014; Smith et al., 2014; York and Venkataraman, 2010), a 37-item SE performance assessment was developed by the research team, which was scored using a 6-point Likert-type scale ranging from 1 (strongly disagree) to 6 (strongly agree). The research participants were instructed to determine the level of agreement with each SE performance item. Regarding the face validity of the assessment, five experts of agricultural extension were invited to provide feedback in selecting items and constructing the scale to fulfil the aim of assessing SE performance. This scale was then completed by approximately 50 social entrepreneurs to test its readability and flow.

Procedures. The paper-and-pencil survey was administered during three conferences on social entrepreneurship held in Taipei during October 2014. Identical procedures were followed during each assessment. Furthermore, the assessments were conducted by the researchers directly. Therefore, any problems faced by the participants when answering the questions could be resolved. The participants were asked to express their agreement levels regarding how they successfully operate SEs. The questions in this study did not include sensitive items that may have caused the respondents to represent themselves dishonestly because of a desire for social acceptability. In addition, participation was voluntary, confidential, and anonymous to reduce the possibility of social desirability bias. Participants had the right to review the results of their responses.

\section{Results}

Descriptive analysis. Data were analysed using SPSS Version 17.0. The measured items were organised by item analysis on the mean range of SE performance (4.22 to 5.24), standard deviation (0.627 to 1.019), skewness $(-0.998$ to 0.253$)$, and kurtosis (-1.846 to 1.315$)$ of the data acquired during the formal survey. In determining the reliability of the scale, Cronbach's alpha reliability coefficient was analysed $(\alpha>.6)$. To calculate the item discrimination, the means of the participants involved in the $27 \%$ bottomtop groups were compared through an independent samples t test, indicating the significance level achieved. An item-total correlation test was then performed to check if any item in the scale was inconsistent with the averaged behaviour, also indicating the significance level achieved. The results of the aforementioned analyses showed that the measured items were appropriate. 
Exploratory factor analysis. The Kaiser-Meyer-Olkin measure in this study was 0.855 . Bartlett's test of sphericity was significant $\left(\chi^{2}=4317.146\right.$, $\mathrm{df}=666, \mathrm{p}=.000$ ). Both analyses showed that the sampling was sufficient to proceed to the factor analysis. A Principal Axis Factoring (PAF) analysis with promax rotation was conducted to determine the dimensionality of the SEPS. Based on the proven criteria, four-factor solutions (eigenvalues greater than 1) with explained variables of $47.502 \%$ provided the optimal factor structure, conceptually and statistically. Factor 1 included items related to entrepreneur and human resources and was labelled personal issues. Factor 2 included items related to social problems, contributions, and supports and was labelled social aspects. Factor 3 included items related to organisational structure, resources, and operations, and was labelled business elements. Factor 4 included items related to the design and delivery of service programmes and was labelled service programmes.

The Cronbach's $\alpha$ value of Factor 1 was 0.850 ; the value of Factor 2 was 0.870; the value of Factor 3 was 0.896; and the value of Factor 4 was 0.859 . The high value of internal consistency showed that the developed scale had appropriate reliability estimates. The M, SD, and PAF results of Study 1 are listed in Table 1. The correlation coefficients between the four different factors ranged from 0.384 to 0.547 .

Table 1. The PAF loading, $M$, and SD of the SEPS $(n=190)$

\begin{tabular}{|c|c|c|c|}
\hline Factor/item & PAF & M & SD \\
\hline \multicolumn{4}{|l|}{ Personal issues } \\
\hline $\begin{array}{l}\text { 1. Social entrepreneurs have a driving force to improve human } \\
\text { society. }\end{array}$ & .678 & 4.58 & .811 \\
\hline $\begin{array}{l}\text { 2. Social entrepreneurs have concrete resolutions in dealing with } \\
\text { particular social problems. }\end{array}$ & .451 & 4.54 & .821 \\
\hline $\begin{array}{l}\text { 3. The charisma of social entrepreneurs leads to their enterprises } \\
\text { being supported by the public. }\end{array}$ & .633 & 4.51 & .919 \\
\hline $\begin{array}{l}\text { 4. A social enterprise represents its operator's aspirations and career } \\
\text { goal. }\end{array}$ & .786 & 4.45 & .845 \\
\hline 5. Social entrepreneurs consider realistic profit. & .578 & 4.54 & .852 \\
\hline $\begin{array}{l}\text { 6. The greater members' understanding of the meaning of social } \\
\text { enterprises is, the greater organisational development is. }\end{array}$ & .811 & 4.85 & .931 \\
\hline $\begin{array}{l}\text { 7. The greater the members' understanding of the concept of } \\
\text { social enterprises is, the greater the contribution of innovative } \\
\text { development is to the organisation. }\end{array}$ & .397 & 4.95 & .831 \\
\hline $\begin{array}{l}\text { 8. All members generate positive energy because of the operation } \\
\text { mode of a social enterprise. }\end{array}$ & .493 & 4.65 & .760 \\
\hline $\begin{array}{l}\text { 9. Recruiting experienced social enterprise operators is beneficial for } \\
\text { the development of a social enterprise. }\end{array}$ & .348 & 4.94 & .821 \\
\hline
\end{tabular}




\begin{tabular}{|c|c|c|c|}
\hline Factor/item & PAF & M & SD \\
\hline \multicolumn{4}{|l|}{ Social aspect } \\
\hline $\begin{array}{l}\text { 10. Causing positive societal changes is the contribution towards } \\
\text { promoting social enterprises. }\end{array}$ & .678 & 5.17 & .722 \\
\hline $\begin{array}{l}\text { 11. Providing improvement methods for specific social problems is } \\
\text { the contribution towards promoting social enterprises. }\end{array}$ & .451 & 4.83 & .669 \\
\hline $\begin{array}{l}\text { 12. Providing public education for specific social problems is the } \\
\text { contribution towards promoting social enterprises. }\end{array}$ & .633 & 4.62 & .826 \\
\hline $\begin{array}{l}\text { 13. Shaping public service ethos is the contribution towards } \\
\text { promoting social enterprises. }\end{array}$ & .786 & 4.65 & .754 \\
\hline $\begin{array}{l}\text { 14. Gaining public recognition and support is the contribution } \\
\text { towards promoting social enterprises. }\end{array}$ & .578 & 4.60 & .747 \\
\hline $\begin{array}{l}\text { 15. Gaining media attention and creating a social movement is the } \\
\text { contribution towards promoting social enterprises. }\end{array}$ & .811 & 4.37 & .903 \\
\hline $\begin{array}{l}\text { 16. Providing an innovative operation model that can be extended or } \\
\text { learned is the contribution towards promoting social enterprises. }\end{array}$ & .397 & 4.68 & .929 \\
\hline $\begin{array}{l}\text { 17. Improving cooperation networks among business sectors is to } \\
\text { the contribution towards promoting social enterprises. }\end{array}$ & .493 & 4.62 & .888 \\
\hline $\begin{array}{l}\text { 18. Innovative strategies for social (or environmental) changes are } \\
\text { necessary for the operations of social enterprises. }\end{array}$ & .428 & 4.91 & .843 \\
\hline
\end{tabular}

\section{Business elements}

19. Social enterprises must set a clear target market.

$\begin{array}{lll}.503 & 4.96 & .835 \\ .803 & 4.83 & .883 \\ .791 & 5.04 & .819 \\ .478 & 4.96 & .765 \\ .708 & 5.24 & .627 \\ .667 & 5.01 & .749 \\ .695 & 4.91 & .784 \\ .702 & 4.77 & .884 \\ .608 & 4.73 & .803 \\ .350 & 4.22 & 1.019 \\ .577 & 4.97 & .759 \\ .383 & 4.99 & .816 \\ .591 & 4.98 & .709\end{array}$

20. Social enterprises must have a clear business model for commercial gain.

21. Social enterprises must consider the basic profit and the cost structure of the organisation.

22. Social enterprises must recruit appropriate manpower.

23. Social enterprises must improve financial management to reduce organisational risks.

24. Social enterprises must have an organisational structure that can support healthy functioning.

25. Social enterprises must have cooperation networks among business sectors.

26. Social enterprises must be legally established.

27. Social enterprises must have a thorough plan for resource fundraising.

28. Social enterprises must make effective investments.

29. Social enterprises must have a feasible procedure for using enterprise resources.

30. Social enterprises must research and develop innovative service programmes that have social value.

31. Social enterprises must have a thorough marketing plan for service programmes. 


\begin{tabular}{|c|c|c|c|}
\hline Factor/item & PAF & M & SD \\
\hline \multicolumn{4}{|l|}{ Service programmes } \\
\hline $\begin{array}{l}\text { 32. Recruiting volunteers, interns, or disadvantaged groups } \\
\text { to participate in service programmes is a crucial task of social } \\
\text { enterprises. }\end{array}$ & .576 & 4.66 & .899 \\
\hline $\begin{array}{l}\text { 33. Creating service programmes with disadvantaged groups is a } \\
\text { crucial task of social enterprises. }\end{array}$ & .623 & 4.82 & .805 \\
\hline $\begin{array}{l}\text { 34. Gaining public recognition for service programmes is a crucial } \\
\text { task of social enterprises. }\end{array}$ & .733 & 4.86 & .818 \\
\hline $\begin{array}{l}\text { 35. Creating and promoting service programmes compatible with } \\
\text { the parent organisation or institution is a crucial task of social } \\
\text { enterprises. }\end{array}$ & .874 & 4.70 & .848 \\
\hline $\begin{array}{l}\text { 36. Creating and promoting service programmes by revitalising the } \\
\text { existing organisation is a crucial task of social enterprises. }\end{array}$ & .903 & 4.76 & .832 \\
\hline $\begin{array}{l}\text { 37. Improving interaction among the community, customers, and } \\
\text { enterprise is a crucial task of social enterprises. }\end{array}$ & .480 & 4.91 & .919 \\
\hline
\end{tabular}

\section{Discussion}

The four-factor model of the SEPS was applicable to Taiwanese SEs, concurring with previous studies (Arena et al., 2014; Dean \& McMullen, 2007; De Clercq, Dimov \& Thongpapanl, 2013; Kreiser et al., 2013; Meyskens et al., 2010; Smith et al., 2014; York \& Venkataraman, 2010). According to the results, personal issues refer to the motivation, leadership, and charisma of entrepreneurs, as well as the shared knowledge, orientation, and intensity of human resources in a SE.

Social aspects refer to the contributions of a SE in improving local and global environmental conditions and creating positive social changes by addressing particular societal needs, promoting public awareness and social movements, and creating innovative and sustainable products, services, and institutions. Social aspects also refer to the assistance of external institutions in achieving their goals by amplifying cooperation networks amongst businesses.

Business elements refer to the organisational capacity that facilitates the resolution of particular social problems. This dimension includes human resources (e.g., innovation and knowledge transferability), financial resources (e.g., financial plans and systems), organisational structures (including infrastructures), organisational cultures, business models, operational strategies (including target markets and marketing plans), external relations, and legal and regulatory environments.

Finally, service programmes refer to the design and delivery of service programmes that contribute to resolving social problems by increasing social ties amongst enterprises, customers, communities, and the public. 


\section{STUDY 2: CONFIRMATORY FACTOR ANALYSIS AND MEASUREMENT INVARIANCE}

\section{Method}

Participants. The participants in Study 2 were either leaders or high-level managers of SEs in Taiwan. These participants served as the validation sample for verifying the established structure of the SEPS, using a confirmatory factor analysis (CFA). Of the 247 participants, 236 completed all parts of this study. The majority (61.86\%) were male; $24.15 \%$ did not have bachelor's degrees, $33.48 \%$ had bachelor's degrees, and $42.37 \%$ had master's (and above) degrees; $15.68 \%$ ranged in age from 20 to 30 years, 33.49\% ranged from 31 to 40 years, $29.66 \%$ ranged from 41 to 50 years, and $21.17 \%$ ranged from 51 and above.

Procedures. In Study 2, a web-based SEPS was developed and administered by the research team during November 2014. The Survey Monkey tool was chosen to host this study because the program was easy to use and economical. The disadvantages of the Internet survey included contacting the individuals in the targeted population as well as persuading those individuals to complete the survey once they had been contacted. To minimise these possible disadvantages, the survey web address was sent by email, which provided a convenient and immediate means of response for the participants. A list of over 1,000 SEs was obtained from the Ministry of the Interior in Taiwan. The participants were asked to express their agreement levels regarding how they successfully operate SEs. Participation was voluntary and confidential. The results were delivered in aggregate and anonymous form and the data remained private, but could be shared with others if the researchers consented. In addition to the CFA, a series of invariance tests were conducted by the research team across genders.

\section{Results}

Confirmatory factor analysis. CFA with a maximum likelihood estimator was performed using LISREL 8.80 to test the factorial validity of the four-factor solution of the SEPS. The indicators recommended by Tabachnick and Fidell (2001) were used by the research team to assess the goodness of model fit. Regarding the SEPS, the four-factor solution yielded an acceptable fit $\left(\chi^{2}=\right.$ 1694.90, $\mathrm{df}=623, \mathrm{p}<.005, \mathrm{RMSEA}=.086, \mathrm{SRMR}=.090, \mathrm{CFI}=.93, \mathrm{NFI}=$ $.89, \mathrm{TLI}=.92)$. The results of the CFA are illustrated in Table 2 . The tests of reliability and validity of the SEPS are reported in Table 3. 
Table 2. The confirmatory factor analysis of the SEPS $(n=236)$

\begin{tabular}{lllll}
\hline Item/Factor & Personal issues & Social aspect & $\begin{array}{l}\text { Business } \\
\text { elements }\end{array}$ & Service programs \\
\hline 1 & 0.52 & 0.52 & 0.61 & 0.51 \\
2 & 0.55 & 0.63 & 0.57 & 0.50 \\
3 & 0.65 & 0.74 & 0.70 & 0.78 \\
4 & 0.71 & 0.69 & 0.56 & 0.87 \\
5 & 0.50 & 0.68 & 0.74 & 0.80 \\
6 & 0.74 & 0.55 & 0.74 & 0.65 \\
7 & 0.64 & 0.72 & 0.71 & \\
8 & 0.68 & 0.67 & 0.39 & \\
9 & 0.60 & 0.52 & 0.63 & \\
10 & & & 0.45 & \\
11 & & & 0.61 & \\
12 & & & 0.59 & \\
13 & & & 0.60 & \\
\hline
\end{tabular}

Table 3. The composite reliability, convergent validity, and discriminant validity of the SEPS $(n=236)$

\begin{tabular}{lllll}
\hline Factors & $\begin{array}{l}\text { Compos- } \\
\text { ite reli- } \\
\text { ability }\end{array}$ & $\begin{array}{l}\text { Measure- } \\
\text { ment } \\
\text { errors }\end{array}$ & $\begin{array}{l}\text { Convergent } \\
\text { validity (fac- } \\
\text { tor loadings) }\end{array}$ & $\begin{array}{l}\text { Discriminant validity } \\
\text { (confidence intervals) }\end{array}$ \\
\hline 1. Personal issues & .8513 & $.45 \sim .75$ & $.50 \sim 74$ & $\phi 1,2: .6816 \sim .8384 ; \phi 1,3:$ \\
2. Social aspect & .8606 & $.46 \sim .73$ & $.52 \sim .74$ & $.5524 \sim .7876 ;$ \\
3. Business elements & .8853 & $.45 \sim .85$ & $.50 \sim .74$ & $.49 . .3828 \sim .6572 ; \phi 2,3:$ \\
4. Service programs & .8471 & $.24 \sim .75$ & $.50 \sim .87$ & $\phi 2,4: .4524 \sim .6876 ; \phi 3,4:$ \\
\hline
\end{tabular}

According to the data, the analysis of the composite reliability estimates demonstrated that the SEPS had a strong internal consistency. In Study 2, the construct validity was examined in terms of convergent validity and discriminant validity. The convergent validity of each factor was tested by examining the standardised factor loadings. Factor loadings should be .50 or higher for the convergent validity to be achieved. The discriminant validity in this study was tested using confidence interval tests. If the confidence intervals did not include a value of one, discriminant validity was demonstrated. The results reported in Table 3 suggested that convergent and discriminant validity were assured and therefore that the construct validity was also achieved. 


\section{Measurement invariance}

The degree of measurement invariance of the SEPS across genders was further tested by the research team using the steps proposed by Vandenberg and Lance (2000). As shown in Table 4, configural invariance was supported. Whether different degrees of measurement were invariant across genders was then examined by the research team, including factor loadings (metric invariance), response tendency (scalar invariance), factor covariance, factor variance, and error variance. Except for $\chi^{2}$ and $\Delta \chi^{2}$, which are sensitive to large samples, other goodness-of-fit indices, including $\Delta \mathrm{CFI}$, which was proposed to test the measurement invariance, indicated that all models assuming different degrees of invariance were acceptable. The SEPS attained a high degree of measurement invariance across genders. The relationships of covariates with the four SEPS factors were also found to be invariant (structural invariance).

Table 4. The measurement invariance tests of the SEPS $(n=236)$

\begin{tabular}{llllllll}
\hline Problem & $\mathbf{\chi 2}$ & $\mathbf{2} \mathbf{2}$ & df & RMSEA & TLI & CFI & $\Delta$ CFI \\
\hline $\begin{array}{l}\text { Configural } \\
\text { Invariance }\end{array}$ & 4217.1688 & & 1246 & 0.1140 & 0.8308 & 0.8417 & \\
Metric Invariance & 4256.4417 & 39.2729 & 1279 & 0.1130 & 0.8348 & 0.8414 & -0.0003 \\
$\begin{array}{l}\text { Scalar Invariance } \\
\text { Factor Covariance }\end{array}$ & 4313.0191 & 56.5774 & 1312 & 0.1119 & 0.8377 & 0.8401 & -0.0013 \\
$\begin{array}{l}\text { Invariance } \\
\text { Factor Variance }\end{array}$ & 4341.5808 & 18.524 & 1318 & 0.1121 & 0.8378 & 0.8395 & -0.0006 \\
$\begin{array}{l}\text { Invariance } \\
\text { Error Variance }\end{array}$ & 4448.3431 & 106.7623 & 1359 & 0.1141 & 0.8387 & 0.8354 & -0.0037 \\
Invariance & & & 1322 & 0.1121 & 0.8379 & 0.8391 & -0.0004 \\
$\begin{array}{l}\text { Structural } \\
\text { Invariance }\end{array}$ & 4464.1861 & 15.843 & 1363 & 0.1140 & 0.8386 & 0.8348 & -0.0006 \\
\hline
\end{tabular}

\section{Discussion}

A confirmatory factor analysis was conducted to verify the established factor structure in Study 1. The results of the CFA confirmed the four-factor solution of the SEPS. Based on the satisfactory results of internal consistency and cumulative explained variance in Study 1 , the reliability and validity of the ESPS were continually examined by the research team in this study. As a result, the composite reliability and construct validity analyses also supported the effectiveness of the ESPS. Additionally, in this study, the four-factor model of the ESPS was confirmed across genders in Taiwanese SEs to ensure the quality of the assessment. 


\section{STUDY 3: HYPOTHESIS TESTING AND MODEL BUILDING}

\section{Method}

Participants. A list of SEs was obtained by the research team from the Taiwanese government. Excluding the sample used in Study 2, the web-based SEPS was continually administered during December 2014. The survey web address was sent by email to invite SE leaders to participate in Study 3. Of the 292 participants, 280 completed all parts of this study. The majority (61.79\%) were male; $20.36 \%$ did not have bachelor's degrees, $32.14 \%$ had bachelor's degrees, and $47.5 \%$ had master's (and above) degrees; $19.64 \%$ ranged in age from 20 to 30 years, $28.93 \%$ ranged from 31 to 40 years, $31.43 \%$ ranged from 41 to 50 years, and $20 \%$ ranged from 51 and above.

\section{Measure}

In addition to the SEPS, Study 3 adopted the 40 -item IEBFMM (Thompson, 2008), which were measured using a 6-point Likert-type scale ranging from 1 (strongly disagree) to 6 (strongly agree). The IEBFMM items consisted of short phrases that were used to assess the traits typically associated with each of the Big-Five dimensions: extraversion (e.g., talkative, energetic, outgoing), openness (e.g., creative, intellectual, artistic), neuroticism (e.g., envious, anxious, jealous), conscientiousness (e.g., efficient, systematic, organised), and agreeableness (e.g., kind, cooperative, warm). Before the survey was composed, this scale was translated from English to Chinese and then back into English by three independent bilingual researchers to ensure equivalency of meaning (Brislin, 1980).

\section{Procedures}

The procedure of Study 3 was similar to that of Study 2. A total of 755 emails were sent, followed by reminders 2 weeks later. Phone numbers and email addresses were provided on the scales. Therefore, problems encountered by participants when answering the scales could be resolved directly. All participation was voluntary and anonymity was guaranteed. No particular incentives were offered for participation, accounting for the low participation rate $(292 / 755=39.6 \%)$. Of the returned emails, 280 were valid.

\section{Results}

Confirmatory factor analysis. CFA with a maximum likelihood estimator was again performed to examine the factorial validity of the four-factor solution of the SEPS and the five-factor solution of the IEBFMM. Regarding the SEPS, 
the four-factor solution yielded an acceptable fit $\left(\chi^{2}=2325.34, \mathrm{df}=623, \mathrm{p}<\right.$ $.005, \mathrm{RMSEA}=.086, \mathrm{SRMR}=.087, \mathrm{CFI}=.93, \mathrm{NFI}=.90, \mathrm{TLI}=.93)$. The results of the CFA indicated that the loadings of personal issues ranged from .51 to .69 ; those of the social aspects ranged from .52 to .75 ; those of the business elements ranged from .50 to .78; and those of service programmes ranged from .55 to .81 . Discriminant and construct validity were assured.

Regarding the IEBFMM, the four-factor solution yielded an acceptable fit $\left(\chi^{2}=363.47, \mathrm{df}=80, \mathrm{p}<.005, \mathrm{RMSEA}=.098, \mathrm{SRMR}=.066, \mathrm{CFI}=.95, \mathrm{NFI}=.93\right.$, $\mathrm{TLI}=.93$ ). The results of the CFA indicated that the loadings of extraversion ranged from .90 to .93; those of openness ranged from .61 to .99; those of neuroticism ranged from .79 to .95; those of conscientiousness ranged from .91 to .96; and those of agreeableness ranged from .75 to .78. Discriminant and construct validity were also achieved.

Structural equation model. Structural equation modelling combined with maximum likelihood estimation was performed using LISREL 8.80 to test the effects and structural model. In addition to the direct effects of personality traits on perceived SE performance, the data revealed curvilinear relationships between neuroticism and perceived SE performance as well as between agreeableness and perceived SE performance. The data suggested that extraversion, openness, and conscientiousness partially predicted perceived SE performance, which partially supported H1. Neuroticism and agreeableness had positive, direct effects on perceived SE performance, indicating that $\mathrm{H} 2$ was not supported.

The data also suggested curvilinear relationships of the U-shaped curve between neuroticism and two dimensions of SE performance (personal issues and social aspects), which partially supported H5. The data also suggested curvilinear relationships of the inverted U-shaped curve between agreeableness and the four dimensions of SE performance, which partially supported H7. Furthermore, the results suggested that the hypothesised curvilinear relationships between extraversion, openness, and conscientiousness and the perceived SE performance did not exist, indicating that $\mathrm{H} 3, \mathrm{H} 4$, and $\mathrm{H} 6$ were not supported. The curvilinear effects of neuroticism and agreeableness on the four dimensions of perceived SE performance are illustrated in Figures 1, 2, 3, and 4. 


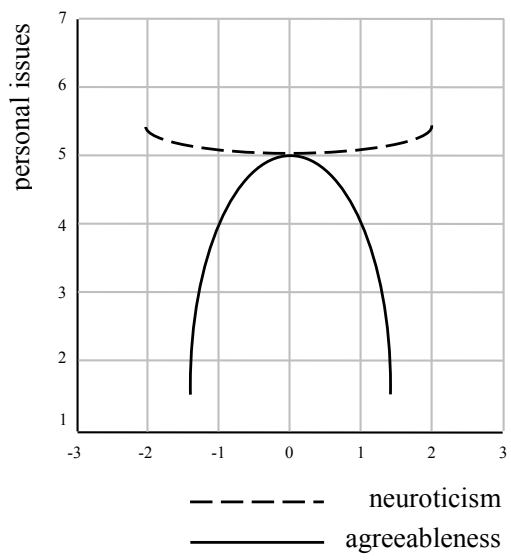

Figure 1. The curvilinear effects of neuroticism and agreeableness on the dimension of personal issues $(n=280)$

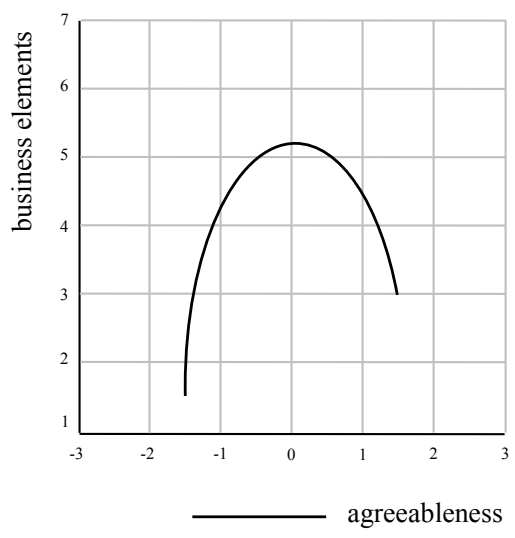

Figure 3. The curvilinear effect of agreeableness on the dimension of business elements $(n=280)$

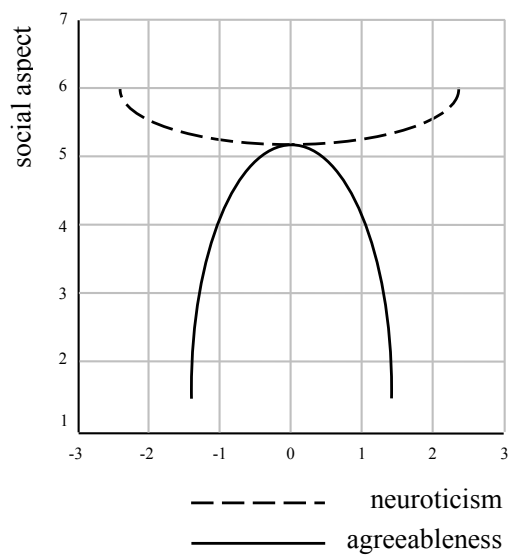

Figure 2. The curvilinear effects of neuroticism and agreeableness on the dimension of social aspect $(n=280)$

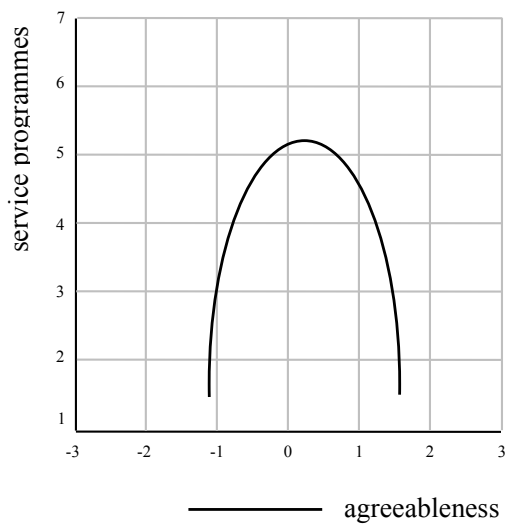

Figure 4. The curvilinear effect of neuroticism on the dimension of service programmes $(n=280)$

The structural models were initially supported, but not all the variables were significantly associated with the four dimensions of perceived SE performance. The research team removed paths that were nonsignificant and subsequently revised the structural model (Figure 5 ). The revised model 
produced a model fit comparable to that of the initial model $\left(\chi^{2}=6480.20\right.$, df $=1929, \mathrm{p}<.005, \mathrm{RMSEA}=.085, \mathrm{SRMR}=.097, \mathrm{CFI}=.86, \mathrm{NFI}=.81, \mathrm{TLI}=.85)$. In addition to the aforementioned curvilinear effects, extraversion positively predicted the service programmes. Openness negatively predicted the service programmes. Neuroticism and conscientiousness positively predicted personal issues and service programmes. Finally, agreeableness positively predicted all dimensions of perceived SE performance.

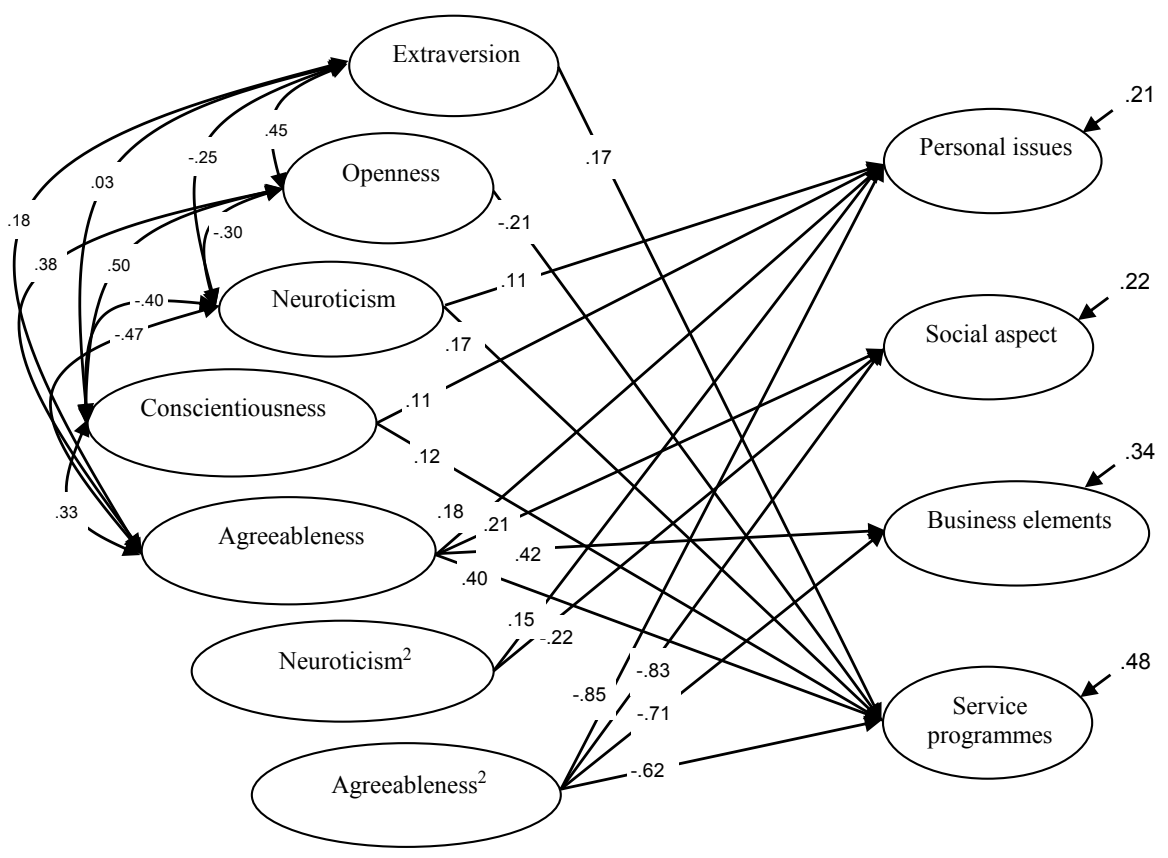

Figure 5. The structural model of personality traits on the perceived SE performance $(n=280)$

\section{Discussion}

Extraversion is a robust predictor of team-based performance (Zabelina et al., 2007), which explains why this trait can predict the service programmes dimension, particularly the delivery of service programmes and the increasing of social ties. People possessing openness have difficulty focusing on tasks that require intense concentration or patience (Rose et al., 1994), which explains why this trait negatively influences the service programmes dimension, as most social problems cannot be resolved overnight. People exhibiting high levels of neuroticism tend to provide others with candid feedback regarding their actions, which can stimulate additional ideas or 
increase team performance (Baer et al., 2008). This trait thus has a positive impact on personal issues and service programmes. Conscientious people tend to be responsible, ambitious, and achievement-oriented. This trait is considered a reliable predictor for entrepreneurs, explaining why it positively influences personal issues and service programmes. Agreeableness is also a robust predictor of team-based performance (Lin et al., 2015), which is particularly crucial for social entrepreneurship. This trait had a strong influence on the dimensions of business elements and service programmes in the current study.

Regarding curvilinear effects, people with high neuroticism scores tend to be insecure and vulnerable (Rothmann \& Coetzer, 2003), which may cause them to agree upon teamwork (personal issues) and social problems (social aspects). However, people with low neuroticism scores tend to be self-confident and calm (Zhao \& Seibert, 2006), which may cause them to appreciate entrepreneurship (personal issues) and social contributions (social aspects). In addition, people possessing high levels of agreeableness can be excessively self-effacing and avoid conflicts (Bernardin et al., 2000), which may diminish social contributions (social aspects) and performance at team or organisational levels (personal issues, business elements, and service programmes). By contrast, people possessing low levels of agreeableness typically prioritise self-interest over cooperating with others (Costa \& McCrae, 1992), which is harmful for any organisation and society as a whole.

\section{GenERAL Discussion}

As previously mentioned, thus far, SE performance has been measured primarily through the case study method with the social return on investments (SROI). Because of limited data collection methods, this study developed a new self-report measure of SE performance that is empirically valid and easy to administer. This measuring tool is convenient and can be used either for self-assessment or client evaluation purposes. Departing from the results, this study considered the following questions regarding future research: how can the measure developed in this study be linked to SROI? What specific factors should be considered in using the SEPS in various domains (e.g., agriculture, social welfare, community services)? What are the implications of these differentiations? What factors influence these differentiations? How do the functioning and influence of these factors differ at the individual, team, organisational, societal, and global levels? The research team anticipates that answering the aforementioned questions may yield valuable insights into the development and operation of SEs. 
According to the results obtained, a SE performance can be assessed using four major dimensions: personal issues, social aspects, business elements, and service programmes. Personal issues refer to the motivation and leadership of entrepreneurs as well as the orientation and intensity of human resources in a SE. Social aspects refer to the contributions of SEs in improving socioenvironmental conditions through addressing the needs of the public, proposing solutions to public issues, promoting public awareness, stimulating social movements, and creating innovative products, services, and institutions. Business elements refer to the organisational capacities, resources, strategies, and operations that facilitate the resolution of social problems. Finally, service programmes refer to the design and delivery of sustainable services and activities to resolve social problems. The extent to which each dimension may be applied warrants further investigation. For example, compared with business elements, the application of service programmes seems to be narrow in focus. The effectiveness of integrating these two dimensions could be analysed in the future.

Openness had only a minor influence on the perceived SE performance, and neuroticism had a positive effect on the SE performance. Although possible explanations and inferences were provided, many open questions require clarification, particularly regarding the contribution of intrinsic characteristics in shaping entrepreneur behaviour and social entrepreneurship. For example, in addition to the dual goals of social entrepreneurs, addressing social issues and generating revenue through trade, what other factors differentiate social entrepreneurs from general entrepreneurs? How do intrinsic characteristics, such as personality traits, influence these differences? How can these influences enhance the job performance of social entrepreneurs? What other intrinsic characteristics (e.g., motivation, emotions, or self-efficacy) affect their performance? What are the major contextual factors interacting with these intrinsic characteristics, and how do they interact? All of these questions warrant future investigation.

Accordingly, the agreeableness trait had dominant influences on all dimensions of the perceived SE performance. Although this result is not entirely compatible with previous entrepreneurship studies (Brandstätter, 2011; Zhao \& Seibert, 2006), it may illustrate the need to re-examine the relationships between personality traits and entrepreneurship in specific domains (e.g., social entrepreneurship). Several uncertainties, including the lack of influences of extraversion and openness on personal issues, the indistinguishable effects of openness and conscientiousness on social aspects, and the minor impact of most traits on business elements, warrant investigation beyond the current study. Information regarding which traits or capacities can benefit which performance dimensions is crucial to the optimal deployment of human 
resources within a SE, which can maximise the contributions of a SE. The answers to these questions can provide insights into employee recruitment, development strategies, and retention policies in SEs.

Before presenting the broad conclusions of this study, some limitations should be acknowledged. First, the samples collected in this series of studies were not large enough to be generalised. Because of this limitation, the research team was unable to analyse data more precisely. For example, establishing various structural models for the various SE domains (e.g., agriculture, social welfare, community services) and examining the possible mediating or moderating models could benefit academia and industry. A second limitation was the feasibility of using SEPS in various contexts, particularly in the field of international entrepreneurship (IE) to address global sustainability. Most IE research has been based primarily on assumptions of the recognition, evaluation, and exploitation of economic opportunity (Zahra et al., 2014). However, well-being is a multidimensional concept. Whether the SEPS applies to diverse cultural contexts was not the focus of this study but warrants further investigation.

\section{CONCLUSION}

Despite the aforementioned limitations, the results of the current study provide a new understanding of how SE performance can be assessed more practically than before and how the personality traits of social entrepreneurs predict various dimensions of the SE performance. According to the results, the SE performance can be assessed using four dimensions: personal issues, social aspects, business elements, and service programmes. The newly developed SEPS can be a reliable measure of the SE performance. Regarding the impact of entrepreneurs' personalities, this report concluded that extraversion positively influenced service programmes, whereas openness negatively influenced service programmes. Neuroticism and conscientiousness positively predicted personal issues and service programmes. Agreeableness positively predicted all dimensions of the perceived SE performance. In addition, the results demonstrated curvilinear relationships of the U-shaped curve between neuroticism and two dimensions of the SE performance (personal issues and social aspects). The data also suggested curvilinear relationships of the inverted $\mathrm{U}$-shaped curve between agreeableness and the four dimensions of the SE performance.

The development of SEs in Taiwan is still at an early stage. People who have been working in the field of SEs can initiate a larger movement, educating and inspiring Taiwanese society. The research team believes that Taiwan will follow in the footsteps of successful SEs in the West and enable innovators to make a social impact across Asia, contributing to a globally sustainable society. 


\section{References}

Arena, M., Azzone, G., Bengo, I. (2014). Performance measurement for social enterprises. International Journal of Voluntary and Nonprofit Organizations, 26(2), 649-672.

Ariani, D. W. (2013). Personality and learning motivation. European Journal of Business and Management, 5(10), 26-38.

Austin, J., Stevenson, H., Wei-Skillern, J. (2006). Social and commercial entrepreneurship: Same, different, or both? Entrepreneurship Theory and Practice, 30(1), 1-22.

Baer, M., Oldham, G., Jacobsohn, G. C., Hollingshad, A. B. (2008). The personality composition of teams and creativity: The moderating role of team creative confidence. Journal of Creative Behavior, 42(4), 255-282.

Barrick, M. R., Mount, M. K., Judge, T. A. (2001). Personality and performance at the beginning of the new millennium: What do we know and where do we go next? International Journal of Selection and Assessment, 9(12), 9-30.

Bernardin, H. J., Cooke, D. K., Villanova, P. (2000). Conscientiousness and agreeableness as predictors of rating leniency. Journal of Applied Psychology, 85(2), 232-236.

Bird, B., Schjoedt, L., Baum, J. R. (2012). Entrepreneurs' behavior: Elucidation and measurement. Entrepreneurship Theory and Practice, 36(5), 889913.

Boluk, K. A., Mottiar, Z. (2014). Motivations of social entrepreneurs: Blurring the social contribution and profits dichotomy. Social Enterprise Journal, 10(1), 53-68.

Brandstätter, H. (2011). Personality aspects of entrepreneurship: A look at five meta-analyses. Personality and Individual Differences, 51(3), 222230.

Brislin, R. W. (1980). Translation and content analysis of oral and written material. In: H. C. Triandis, J. W. Berry (Eds.), Handbook of cross-cultural psychology, Vol. 2 (pp. 349-444). Boston, MA: Allyn and Bacon.

Casson, M., Giusta, M. D. (2007). Entrepreneurship and social capital: Analysing the impact of social networks on entrepreneurial activity from a rational action perspective. International Small Business Journal, 25(3), 220-244.

Chell, E. (2007). Social enterprise and entrepreneurship: Towards a convergent theory of the entrepreneurial process. International Small Business Journal, 25(1), 5-26.

Chen, C. C., Greene, P. G., Crick, A. (1998). Does entrepreneurial self-efficacy distinguish entrepreneurs from managers? Journal of Business Venturing, 13, 295-316.

Cohen, B., Winn, M. I. (2007). Market imperfections, opportunity and sustainable entrepreneurship. Journal of Business Venturing, 22(1), 2949. 
Corner, P. D., Ho, M. (2010). How opportunities develop in social entrepreneurship. Entrepreneurship Theory and Practice, 34(4), 635-659.

Costa, P. T., McCrae, R. R. (1992). Revised NEO Personality Inventory (NEO$P I-R$ ) and NEO Five-Factor Inventory (NEO-FFI) professional manual. Odessa, FL: Psychological Assessment Resources.

De Clercq, D., Dimov, D., Thongpapanl, N. (2013). Organizational social capital, formalization, and internal knowledge sharing in entrepreneurial orientation formation. Entrepreneurship Theory and Practice, 37(3), 505537.

Dean, T. J., McMullen, J. S. (2007). Towards a theory of sustainable entrepreneurship: Reducing environmental degradation through entrepreneurial action. Journal of Business Venturing, 22(1), 50-76.

Denissen, J. J. A., Penke, L. (2008). Neuroticism predicts reactions to cues of social inclusion. European Journal of Personality, 22(6), 497-517.

DTI Social Enterprise Unit (2003). A progress report on social enterprise: A strategy for success. London: Department of Trade and Industry's (DTI), Social Enterprise Unit.

Gemmell, R. M., Boland, R. J., Kolb, D. A. (2012). The socio-cognitive dynamics of entrepreneurial ideation. Entrepreneurship Theory and Practice, 36(5), 1053-1073.

Goldberg, L. R. (1992). The development of makers for the Big-Five factor structure. Psychological Assessment, 4, 26-42.

Hadad, S., Găucă, O. (2014). Social impact measurement in social entrepreneurial organizations. Management \& Marketing. Challenges for the Knowledge Society, 9(2), 119-136.

Hall, J. K., Daneke, G. A., Lenox, M. J. (2010). Sustainable development and entrepreneurship: Past contributions and future directions. Journal of Business Venturing, 25(5), 439-448.

Hockerts, K., Wüstenhagen, K. R. (2010). Greening Goliaths versus emerging Davids: Theorizing about the role of incumbents and new entrants in sustainable entrepreneurship. Journal of Business Venturing, 25(5), 481492.

Ilies, R., Johnson, M. D., Judge, T. A., Keeney, J. (2011). A within-individual study of interpersonal conflict as a work stressor: dispositional and situational moderators. Journal of Organizational Behavior, 32(1), 4464.

Katre, A., Salipante, P. (2012). Start-up social ventures: Blending finegrained behaviors from two institutions for entrepreneurial success. Entrepreneurship Theory and Practice, 36(5), 967-994.

Korsgaard, S., Anderson, A. R. (2011). Enacting entrepreneurship as social value creation. International Small Business Journal, 29(2), 135-151.

Kreiser, P. M., Patel, P. C., Fiet, J. O. (2013). The influence of changes in social capital on firm-founding activities. Entrepreneurship Theory and Practice, 37(3), 539-568. 
Krlev, G., Münscher, R., Mülbert, K. (2013). Social return on investment (SROI): State-of-the-art and perspectives: A meta-analysis of practice in social return on investment (SROI) studies published 2000-2012. Centre for Social Investment, Heidelberg University. Retrieved from: $h t t p: / / C S I$ SROI_Meta_Analysis_2013.pdf.

Le, H., Oh, I. -S., Robbins, S. B., Ilies, R., Holland, E., Westrick, P. (2011). Too much of a good thing: Curvilinear relationships between personality traits and job performance. Journal of Applied Psychology, 96(1), 113133.

LePine, J. A. (2003). Team adaptation and postchange performance: effects of team composition in terms of members' cognitive ability and personality. Journal of Applied Psychology, 88(1), 27-39.

Lin, J. -S., Liang, C. -T., Chang, W. -S., Liang, C. (2015). Relation between personality traits and imaginative capability of engineering students. International Journal of Engineering Education, 31(1A), 23-36.

Lin, S. Y. -H. (2009). Taiwanese influence. Retrieved from: http://www. socialenterprise.net/blog/Taiwanese Influence.html.

Marshall, A. Beachy, T. (2010). Questions only a parent would ask: An exercise for evaluating the impact of the social enterprise in your non-profit organization. Vancouver, BC, Canada: Demonstrating Value.

McCrae, R. R., Costa, P. T., Jr. (1991). The NEO personality inventory: Using the five-factor model in counseling. Journal of Counseling and Development, 69(4), 367-372.

Meyskens, M., Robb-Post, C., Stamp, J. A., Carsrud, A. L., Reynolds, P. D. (2010). Social ventures from a resource-based perspective: An exploratory study assessing global Ashoka Fellows. Entrepreneurship Theory and Practice, 34(4), 661-680.

Michel, J. S., Clark, M. A., Jaramillo, D. (2011). The role of the Five Factor Model of personality in the perceptions of negative and positive forms of work-nonwork spillover: a meta-analytic review. Journal of Vocational Behavior, 79(1), 191-203.

Parrish, B. D. (2010). Sustainability-driven entrepreneurship: Principles of organization design. Journal of Business Venturing, 25(5), 510-523.

Pelchat, M. C. (2005). Social entrepreneurship in Taiwan: Possibilities and challenges for empowerment. Paper presented at the 4th ISTR Asia and Pacific Conference, Bangalore, India.

Penney, L. M., David, E., Witt, L. A. (2011). A review of personality and performance: identifying boundaries, contingencies, and future research directions. Human Resource Management Review, 21(4), 297-310.

Rose, R. M., Fogg, L. F., Helmreich, R. L., McFadden, T. J. (1994). Psychological predictors of astronaut effectiveness. Aviation Space and Environmental Medicine, 65(10 Pt 1), 910-915.

Rothmann, S., Coetzer, E. P. (2003). The Big Five personality dimensions and job performance. SA Journal of Industrial Psychology, 29(1), 68-74. 
Saucier, G. (1994). Mini-markers: A brief version of Goldberg's Unipolar BigFive Makers. Journal of Personality Assessment, 63(3), 506-516.

Simon, M., Houghton, S. M., Aquino, K. (2000). Cognitive biases, risk perception, and venture formation: How individuals decide to start companies. Journal of Business Venturing, 15(2), 113-134.

Smith, R., Bell, R., Watts, H. (2014). Personality trait differences between traditional and social entrepreneurs. Social Enterprise Journal, 10(3), 200-221.

Stewart, W. H., Roth, P. L. (2004). Data quality affects meta-analytic conclusions: A response to Miner and Raju (2004) Concerning entrepreneurial risk propensity. Journal of Applied Psychology, 89, 14-21.

Tabachnick, B. G., Fidell, L. S. (2001). Using multivariate statistics, 4th edition. Boston, MA: Allyn and Bacon.

Thompson, E. R. (2008). Development and validation of an International English Big-Five Mini-Markers. Personality and Individual Differences, 45(6), 542-548.

Van Der Molen, H. T., Schmidt, H. G., Kruisman, G. (2007). Personality characteristics of engineers. European Journal of Engineering Education, 32(2), 495-501.

Vitiello, D., Wolf-Powers, L. (2014). Growing food to grow cities? The potential of agriculture foreconomic and community development in the urban United States. Community Development Journal, 49(4), 508-523.

Wang, J.-H., Liang, C. (2015). Empowerment through intrinsic motivation and self-efficacy: How personality traits influence rural practice in agricultural students? In: J. Hawkins (Ed.), Personality traits and types: Perceptions, gender differences and impact on behavior (pp. 109-132). Hauppauge, NY: Nova Science Publishers.

Wolff, H. -G., Kim, S. (2012). The relationship between networking behaviors and the big five personality dimensions. Career Development International, 17(1), 43-66.

Yap, S. C. Y., Anusic, I., Lucas, R. E. (2012). Does personality moderate reaction and adaptation to major life events? Evidence from the British Household Panel Survey. Journal of Research in Personality, 46(5), 477-488.

York, J. G., Venkataraman, S. (2010). The entrepreneur-environment nexus: Uncertainty, innovation, and allocation. Journal of Business Venturing, 25(5), 449-463.

Zabelina, D. L., Robinson, M. D., Anicha, C. L. (2007). The psychological tradeoffs of self-control: A multi-method investigation. Personality and Individual Differences, 43(3), 463-473.

Zahra, S. A., Newey, L. R., Li, Y. (2014). On the frontiers: The implications of social entrepreneurship for international entrepreneurship. Entrepreneurship Theory and Practice, 38(1), 137-158.

Zhao, H., Seibert, S. E. (2006). The Big Five personality dimensions and entrepreneurial status: A meta-analytical review. Journal of Applied Psychology, 91(2), 259-271. 


\section{Biographical notes}

Chao-Tung Liang is an assistant professor in the Department of Cultural Creativity and Digital Media Design, Lunghwa University of Science and Technology, Taoyuan, Taiwan. He gained his Master degree in the Radio and Television program at the National Taiwan University of Arts, Taiwan. His current research interests focus on: communication education, multimedia design, and entrepreneurship.

Li-Pei Peng is an associate professor in the Department of Bio-Industry Communication and Development, National Taiwan University, Taipei, Taiwan. He obtained his Ph.D. degree in Department of Urban Engineering from the University of Tokyo in Japan in 2008. His research interests cover rural planning, cultural landscape conservation, community development, and regional governance.

Shu-Nung Yao is a postdoctoral researcher, Department of Bio-Industry Communication and Development, National Taiwan University, Taipei, Taiwan. He obtained his Ph.D. degree in Department of Electronic Engineering from the University of Birmingham in the United Kingdom in 2008. His research interests cover virtual learning environment, signal processing, and Matlab graphical user interface.

Dr. Chaoyun Liang is a professor in the Department of Bio-Industry Communication and Development, National Taiwan University, Taipei, Taiwan. He gained his PhD in the Instructional Systems Technology program at the Indiana University, USA. His current research interests focus on: imagination \& creativity, entrepreneurship \& social enterprise, and agrirural communication \& marketing.

\section{Abstrakt (in Polish)}

Wobec braku narzędzi pomiaru oraz istnienia luki badawczej w zakresie przedsiębiorczości społecznej, przeprowadzono trzy badania majqce na celu opracowanie nowego sposobu pomiaru wyników przedsiębiorczości społecznej, który byłby trafny empirycznie i łatwy do zastosowania. Opracowane narzędzie pozwala na badanie relacji między cechami osobowości przedsiębiorców i postrzeganiem przez nich wyników w zakresie przedsiębiorczości społecznej. Wyniki wykazały, że przedsiębiorczość społeczna może być oceniana w czterech wymiarach: aspektów osobistych zwiqzanych z przedsiębiorcq, aspektów społecznych, elementów biznesowych, oraz świadczonych usług. Ekstrawersja pozytywnie wpływa na świadczone usługi, natomiast otwartość ma na nie wpływ negatywny. Neurotyczność i sumienność wykazywały pozytywny zwiqzek z aspektami osobistymi przedsiębiorcy i świadczonymi usługami, a ugodowość miała pozytywny zwiqzek z wszystkimi wymiarami postrzeganych wyników przedsiębiorczości społecznej. Wyniki badań wykazały również krzywoliniowy zwiqzek w kształcie litery U pomiędzy neurotycznościq i aspektami osobistymi przedsiębiorcy oraz aspektami społecznymi wyników przedsiębiorczości społecznej. Ponad- 
to, zaobserwowano krzywoliniowq, U-kształtnq zależność pomiędzy ugodowościq a czterema wymiarami wyników przedsiębiorczości społecznej.

Słowa kluczowe: ocena wyników, cechy osobowości, budowa skali pomiarowej, przedsiębiorstwo społeczne, skala pomiaru wyników przedsiębiorstwa społecznego. 